\title{
PENGALAMAN POSTPARTUM BLUES PADA IBU PRIMIPARA
}

\author{
Dian Roza Adila ${ }^{1}$, Defryanti Saputri ${ }^{2}$, Sekani Niriyah ${ }^{3}$ \\ ${ }^{1,2,3}$ Program Studi Ilmu Keperawatan STIKes Hang Tuah Pekanbaru \\ Email: adila_skep@ymail.com
}

\begin{abstract}
Abstrak
Postpartum blues merupakan suatu gangguan psikologis yang dialami ibu pada masa postpartum, yang ditandai beberapa gejala seperti perubahan mood, merasa terlalu emosional, mudah menangis, letih, serta bingung dan pikiran kacau. Gejala tersebut didukung dengan adanya perubahan biologis, stress yang dialami, sosial atau lingkungan. Keadaan tersebut muncul 2 atau 3 hari setelah kelahiran dan akan menghilang 1 atau 2 minggu. Penelitian ini bertujuan untuk mengetahui pengalaman postpartum blues pada ibu primipara. Penelitian ini menggunakan metode kualitatif dengan pendekatan studi fenomenologi. Partisipan pada penelitian ini berjumlah 5 orang ibu yang mempunyai pengalaman postpartum blues. Tehnik sampling yang digunakan adalah purposive sampling. Metode pengumpulan data yang digunakan adalah wawancara mendalam. Data dianalisa dengan menggunakan analisa collaizi. Penelitian ini diperoleh 5 tema terkait pengalaman postpartum blues pada ibu primipara yaitu perubahan tugas perkembangan, faktor penyebab, tanda gejala postpartum blues, penanganan, dan dukungan yang diterima ibu postpartum blues. Hasil penelitian ini diharapkan dapat menambah wawasan dan pengetahuan bagi masyarakat terutama ibu postpartum dalam menghadapi perubahan peran setelah proses melahirkan.

Daftar pustaka: 31 (2005-2017)
\end{abstract}

Kata kunci: postpartum blues, Ibu primipara

\begin{abstract}
Postpartum blues is a psychological disorder experienced by the mother in the postpartum period, which is characterized by several symptoms such as mood changes, emotional feeling, tired, and confused. These symptoms are supported by biological changes, stress experienced, social or environmental. This condition appears about 2 or 3 days after labour and will disappear in 1 or 2 weeks. The aim of this study was to determine the experience of postpartum blues in primiparous mothers. This study uses a qualitative method with phenomenological approach. The participants of this study consist of five mothers who had experience with postpartum blues. The sampling technique used purposive sampling. Depth interviews used as data collection and the data were analyzed using collaizi analysis. There were 5 themes related to experience of postpartum blues in primiparous mothers. The themes are the changes in developmental tasks, causative factors, signs and symptoms of postpartum blues, treatment, and support received by the postpartum blues mothers. The results of this study are expected to enhance knowledge for the community, especially postpartum mothers to face the roles changing after labour.
\end{abstract}

Bibliography: 31 (2005-2017)

Keywords: postpartum blues, primipara mother

\section{PENDAHULUAN}

Kehamilan, melahirkan dan menjadi seorang ibu merupakan hal yang fisiologis. Kelahiran seorang anak akan membawa kebahagian didalam suatu keluarga, namun juga dapat menimbulkan suatu masalah baru terutama bagi seorang ibu. Selama masa pasca persalinan atau yang disebut dengan postpartum, ibu mengalami berbagai perubahan hormon, perubahan hormon tersebut membuat ibu mengalami perubahan emosional seperti yang memicu terjadinya berbagai gangguan psikologis. Salah satu gangguan psikologis tersebut adalah 
Dian Roza Adila ${ }^{1}$, Defryanti Saputri ${ }^{2}$, Sekani Niriyah ${ }^{3}$, Pengalaman Postpartum Blues pada Ibu Primipara

postpartum blues (Notokusumo, 2017; Rai, Pathak \& Sharma, 2015; Menken E, Alexis, Dowd S, Stone, 2008).

Postpartum blues merupakan suatu gangguan psikologis yang dialami ibu pada masa postpartum, yang ditandai beberapa gejala seperti perubahan mood, merasa terlalu emosional, mudah menangis, letih, serta bingung dan pikiran kacau. Gejala tersebut didukung dengan adanya perubahan biologis, stress yang dialami, sosial atau lingkungan. Keadaan tersebut muncul 2 atau 3 hari setelah kelahiran dan akan menghilang 1 atau 2 minggu (Bobak, Lowdermilk \& Jensen, 2005; Quintero, Rojo, Chapela, Mora \& Fellix, 2014).

Angka kejadian postpartum blues di Asia cukup tinggi dan sangat bervariasi yaitu 26\%-85\%, di Indonesia angka kejadian postpartum blues yaitu antara 50\%-70\% dan angka kejadian depresi postpartum pada ibu 11\%-30\% (Notokusumo, 2017). Sedangkan di Pekanbaru sebagai ibu kota Provinsi Riau, berdasarkan hasil penelitian Misrawati, Lestari dan Utami (2014) dalam Desfanita, Misrawati dan Arneliwati (2015) didapatkan sekitar $16,7 \%$ ibu postpartum di RSUD Arifin Achmad mengalami postpartum blues. Di Indonesia sendiri postpartum blues disebabkan kurangnya perhatian tentang postpartum blues, dan diperparah dengan anggapan yang keliru dimana postpartum blues ini dianggap tidak terlalu penting dan hanya sebagai efek samping dari keletihan setelah proses persalinan (Sulistiyanti \& Susanti, 2017).
Postpartum blues sampai saat ini belum diketahui penyebabnya secara pasti, namun ada beberapa faktor yang diduga dapat mempengaruhi kejadian postpartum blues diantaranya seperti perubahan hormon, dimana terjadinya penurunan kadar progesteron dan estrogen saat pengeluaran plasenta. Hormon estrogen tersebut sangat mempengaruhi sistem aktifitas enzim monoamin terutama serotin dan dopamin yang dapat mempengaruhi perubahan suasana hati dan juga terjadinya depresi. Kondisi lain yang mendukung terjadinya postpartum blues adalah kelemahan fisik, dikarenakan aktifitas dalam merawat bayi yang sangat menguras energi sehingga membuat ibu merasa kelelahan dan ditambah dengan tidak adanya bantuan dari keluarga khususnya dari suami (Mansur, 2009; Rai, Pathak \& Sharma, 2015).

Pada masa pascapersalinan ibu yang tidak mendapat dukungan dari suami, memiliki peluang 6,013 kali untuk mengalami depresi postpartum bila dibandingkan dengan ibu yang mendapatkan dukungan dari suami, hal ini dikarenakan suami adalah orang yang terdekat dengan ibu. Suami bertanggung jawab memberikan rasa aman, nyaman, serta memberikan motivasi dalam kehamilan dan persalinan sehingga ibu dapat beradaptasi terhadap perubahan emosi yang dialami dan terhindar dari perasaan depresi (Fairus \& Widiyanti, 2014).

Dukungan keluarga juga sangat mempengaruhi ibu primipara pada masa transisi menjadi orang tua dalam merawat 
bayi. Primipara adalah seorang wanita yang pertama kali menjalani masa kehamilan hingga proses melahirkan janin, baik janin yang dilahirkan tersebut hidup ataupun meninggal. Setelah 6 sampai 8 minggu pascapersalinan, seorang ibu normal mampu menjalani tugasnya sebagai orang tua, namun, pada beberapa ibu sulit menyesuaikan diri dengan peran barunya dan masih memerlukan dukungan dalam menjalani tanggung jawabnya sebagai orang tua (Bobak, Lowdermilk \& Jensen, 2005).

Apabila postpartum blues tidak segera ditangani akan berdampak kepada struktur dan fungsi keluarga, yang akan mempengaruhi peran ibu. Dampak lain seperti kondisi gangguan psikis yang lebih berat yang disebut depresi postpartum, dimana ibu akan merasa bersalah, hilangnya kemauan dalam melakukan aktivitas sehari-hari, ibu juga mengalami penurunan atau bahkan peningkatan berat badan, menarik diri dari lingkungannya tidak mampu mengatasi suatu masalah, serta kekhawatiran akan ketidakmampuan dalam merawat bayi. Pada kondisi yang paling berat, ibu dapat membunuh bayinya sendiri, kondisi tersebut dinamakan dengan psikosis pascapartum.

\section{METODE PENELITIAN}

Penelitian ini, menggunakan jenis penelitian kualitatif, dengan pendekatan fenomenologi deskriptif (Anggraeni \& Saryono, 2013). Penelitian dilakukan di Puskesmas Harapan Raya pada bulan Juli sampai Agustus. Pengambilan data menggunakan teknik purposive sampling, dengan pengumpulan data menggunakan wawancara mendalam (Afiyanti \& Rachmawati, 2014). Keabsahan data diukur dengan partisipan menggunakan triangulasi sumber yaitu partisipan pendukung yang dekat dengan partisipan utama. Jumlah partisipan yaitu 5 orang. Analisa data menggunakan analisa Collaizi lalu ditentukan tema dalam bentuk verbatim (Anggraeni \& Saryono, 2013).

\section{HASIL PENELITIAN}

Pengalaman ibu ketika mengalami postpartum blues diantaranya berupa perubahan tugas perkembangan yang meliputi proses adaptasi menjadi ibu dan kurangnya waktu untuk diri sendiri, selanjutnya faktor penyebab diantaranya merawat anak sendirian, perubahan mood yang tidak menyenangkan, dan keadaan bayi. Selanjutnya tanda gejala postpartum blues pada ibu primipara meliputi bentuk emosional, kondisi fisik ibu pada saat mengalami postpartum blues, dan lamanya ibu mengalami postpartum blues, dan untuk penanganan ketika ibu mengalami postpartum blues yaitu melakukan pengalihan pikiran, bercerita dengan orang terdekat, dan meningkatkan istirahat. Dukungan yang diterima ibu postpartum blues diantaranya orang yang memberikan dukungan dan juga bentuk dukungan. 
Dian Roza Adila ${ }^{1}$, Defryanti Saputri ${ }^{2}$, Sekani Niriyah ${ }^{3}$, Pengalaman Postpartum Blues pada Ibu Primipara

\section{Gambaran Informan}

Partisipan bervariasi dengan usia mulai dari 22-28 tahun, dan partisipan terbanyak bekerja sebagai ibu rumah tangga, sedangkan lama menjadi ibu dengan usia bayi 1 bulan sampai 3 bulan, untuk usia partisipan pendukung bervariasi dengan usia 28-45 tahun. Dimana partisipan pendukung adalah orang yang terdekat dengan partisipan utama yaitu suami, adik, ibu kandung dan teman terdekat yang rumahnya berdekatan dengan partisipan utama.

\section{Perubahan Tugas Perkembangan}

Pada tema ini diperoleh kategori proses adaptasi menjadi ibu yaitu berupa mengurus anak, belum mengerti cara merawat bayi, belum pernah menyusui, terjadi perubahan dalam diri.

\begin{abstract}
"Jadi ibu untuk pertama kalinya kan bingung mau ngapain, gelisah kek mana cara kita ngerawat bayi kek mana belum tau, cara bedung nya, mandiin nya kek mana caranya, nyusui nya kek mana, kadang ada jugak pikiran mampu tidak merawat bayi kayak gitu...kita kan belum pernah ngurus bayi kan...eeee karna kita nyusuin, menyusui kan belum pernah nyusuin jadinya tu rasanya tu sakit... (pandangan kebawah kekiri dan kekanan)"(P2)
\end{abstract}

\section{Faktor Penyebab}

Faktor pemicu postpartum blues yang dialami partisipan berupa merawat anak sendiri seperti capek mengurus anak, suami yang bekerja, begadang sendirian, jenis persalinan, jauh dari keluarga, tidak mendapat respon dari suami, mengerjakan pekerjaan rumah sendiri. “...sempat ini jugak, kadang kita kan capekkan ngurus anak sendiri, yang bantu gak ada, orang tua pun jauh gak ada, gak ada tinggal sama kita gitu..... suami ada juga bantu, cumak dia kan kerjanya sampek pulang pagi gitu, dia jaga ini,,, jaga apotik kan 24jam...(bersandar ditempat tidur)"(P1)

\section{Tanda gejala postpartum blues pada ibu primipara}

Tanda gejala postpartum blues tergambar dari perubahan emosional yang dialami partisipan selama masa postpartum blues berupa marah, menangis, tersinggung, gelisah, sedih, senang, cemas, bingung, emosi.

"Merasa lelah, capek, rasanya bawaannya mau marah aja, tapi gak bisa,,,,mau marah sama siapa, jadi nangis aja jadinya (tangan memengang telapak kaki)"(P2)

“...bingungnya banyak hal,,,namanya kita baru anak pertama,,bingung gimana cara ngerawatnya, takut ASI yang belum keluar, banyak hal lah hehehehe....sering uringuringan, marah-marah nggak menentu Ahirnya pelampiasannya tu pengen marah aja, kayak nggak bisa ngontrol diri....(memainkan kedua tangan)"'(P5)

\section{Penanganan}

Penanganan postpartum blues partisipan terlihat dari kategori pengalihan pikiran seperti bermain handphone, menonton televisi, membuka youtube, mencari hiburan, meminta dibuatkan makanan.

"Ya paling untuk ngilangin stres, suntuk gitu ya biar nggak terlalu dipikirin kali... untuk ngilanginnya ya main-main hape, nonton tivi gitu, buka-buka youtube...(melihat ke handphone)" (P1)

"Carik hiburan ya mainan hape, nonton tivi atau kadang ada temen crita-crita gitu aja...ya paling ngalihkan pikirannya 
aja ntah eee apa minta bikinin makanan apa yang kira-kira boleh dimakan gitu kan...(menimang bayi)" (P4)

\section{Dukungan}

Dukungan yang diterima partisipan saat mengalami masa postpartum blues berasal dari suami, orang tua, mertua, adik dan teman atau tetangga.

"Kalok dari orang tua mbak sendiri sih ngasih support,,,memang udah rejekinya kayak gini mau kek mana lagi ya harus diterima, kalok dari suami ya ngasih dukungan biar maksudnya biar kuat, biar nerima kondisi anak, adek gitu jugak ngasih dukungan, ngasih support, dari mertua semualah pada ngasih dukungan ngasih support aja (melihat ke bayi)" (P3)

"Ya kalok orang tua khususnya ibuk gitu ngasih pengarahan, soalnya baru anak pertama kan harus hati-hati, dijaga badan jugak kan. Katanya kalok dari awal bisa njaga insaallah seterusnya tetep bagus gitu. Tapi kalok dari suami ya paling cumak ngasih nasehat apa sabar gitu suruh tenang gitu aja (menimang bayi)" (P4)

"Itu alhamdulillah ada temen-temen atau tetangga yang dekat rumah, sering datang kerumah ngobrol, cerita, itulah yang menjadi hiburan untuk melepaskan rasa lelah rasa stres (menggaruk kaki)" (P5)

\section{PEMBAHASAN}

\section{Perubahan tugas perkembangan}

\section{- Proses adaptasi menjadi ibu}

Hasil penelitian ini didapatkan proses adaptasi partisipan dalam menjadi seorang ibu yaitu berupa mengurus anak, belum tahu cara merawat bayi, belum pernah menyusui bayi, banyak perubahan dalam diri.

Menurut teori Friedman, Bowden dan Jones (2014) mengatakan adaptasi keluarga merupakan suatu proses yang berlangsung sepanjang waktu terhadap situasi kehidupan yang penuh stress, transisi menjadi orang tua merupakan salah satu kunci siklus dalam kehidupan keluarga, walaupun menjadi orang tua merupakan tujuan yang sangat penting, namun sebagian besar menunjukkan bahwa memasuki masa menjadi orang tua adalah masa kehidupan yang penuh stress. Hal ini sesuai juga dengan teori Bobak, Lowdermilk dan Jensen (2005) yang mengatakan kelahiran seorang anak menimbulkan suatu tantangan mendasar terhadap struktur keluarga yang sudah terbentuk, dan menjadi orang tua dapat menyebabkan ketidakstabilan prilaku dalam transisi menjadi orang tua.

\section{Faktor penyebab}

\section{- Merawat anak sendirian}

Faktor penyebab partisipan mengalami postpartum blues pada penelitian ini berupa mengurus anak sendirian, dirumah sendirian, semua orang kerja, begadang sendirian, dan melakukan aktivitas sendiri.

Menurut Mansur (2009), kejadian postpartum blues sering dialami oleh ibu yang baru melahirkan karena hal ini berhubungan dengan kemampuan atau pengalaman ibu dalam menghadapi masalah-masalah yang terjadi dalam merawat bayinya sendiri. Seorang ibu yang merawat anaknya sendiri tentu belum berpengelaman sehingga memberikan dampak terhadap perawatan yang diberikan kepada bayinya dan mengganggu aktifitasnya sehari hari. 
Dian Roza Adila ${ }^{1}$, Defryanti Saputri ${ }^{2}$, Sekani Niriyah ${ }^{3}$, Pengalaman Postpartum Blues pada Ibu Primipara

Penelitian ini juga sejalan dengan penelitian yang dilakukan Jadri et all,. (2006) dalam Fatmawati (2015) bahwa ibu-ibu primipara belum mempunyai pengalaman dalam merawat anaknya sendiri sehingga timbul rasa takut dan khawatir dalam merawat bayinya sendiri. Begitu pula dalam melakukan tugas sebagai seorang ibu, wanita primipara merasa bingung, lebih terbebani dan merasa kebebasannya berkurang dengan hadirnya seorang anak.

Tanda gejala postpartum blues pada ibu primipara

\section{- Emosional}

Dalam hasil penelitian ini didapatkan tanda gejala partisipan saat mengalami postpartum blues berupa marah, nangis, tersinggung, gelisah, stress, bingung, sedih, cemas, senang dan emosi.

Menurut Bobak, Lowdermilk dan Jansen (2005) mengatakan secara emosional postpartum blues ditandai dengan adanya rasa gelisah, cemas, stress yang berlebihan, bingung, sedih dan menangis. Penelitian ini sejalan dengan hasil penelitian yang dilakukan Andri dalam Kirana (2015) dimana didapatkan hasil tanda gejala dari postpartum blues yaitu berupa kesedihan, suka menangis, hilangnya nafsu makan, mudah tersinggung, dan cemas.

\section{Penanganan}

\section{- Pengalihan pikiran}

Penanganan postpartum blues yang dilakukan partisipan dalam penelitian seperti bermain handphone, menonton televisi, membuka youtube, mencari hiburan dan meminta dibuatkan makanan.

Jhaquin (2010) mengatakan dimana cara lain yang dapat dilakukan untuk mengatasi postpartum blues salah satunya yaitu dengan cara mencari hiburan yang dapat mengalihkan pikiran ibu ketika mengalami postpartum blues hal tersebut bertujuan untuk meningkatkan hubungan baik dan memahami kondisi yang sedang dirasakan oleh ibu. Hal ini sesuai dengan penelitian yang dilakukan Fatimah (2009) bahwa para ibu yang mengalami postpartum blues membutuhkan kesempatan untuk mengekspresikan pikiran dan kesempatan mereka dari situasi yang menakutkan.

\section{Dukungan yang diterima ibu postpartum blues}

\section{- Orang yang memberikan dukungan}

Dalam hasil penelitian ini orang yang memberikan dukungan pada ibu yang mengalami postpartum blues yaitu suami, orang tua, mertua, adik, teman dan tetangga. Menurut teori Friedma, Bowden dan Jones (2014) respon atau koping keluarga merupakan suatu tindakan atau perlakuan khusus yang dilakukan keluarga ketika mengalami suatu permasalahan. Bobak, Lowdermilk dan Jansen (2005) mengatakan pada masa postpartum blues ibu memerlukan dukungan baik dari suami, keluarga, maupun teman terdekat. Meedya, S., Fahy, K., Kable, A (2010) mengatakan adanya dukungan keluarga akan meningkatkan kesejahteraan ibu dan anak, mengingat bantuan tenaga 
professional tidak dapat menggantikan dukungan hari demi hari yang diberikan keluarga terutama suami kepada ibu dan bayinya.

\section{SIMPULAN}

Berdasarkan analisis yang peneliti lakukan pada penelitian ini didapatkan lima tema perubahan tugas perkembangan, faktor penyebab, tanda gejala postpartum blues pada ibu primipara, penanganan, dan dukungan yang diterima ibu postpartum blues.

\section{DAFTAR PUSTAKA}

Anggraeni \& Saryono. (2013). Metodologi Penelitian Kualitatif dan Kuantitatif dalam Bidang Kesehatan. Jakarta: Nuha Medika

Desfanita, Misrawati \& Arneliwati (2015). Faktor-Faktor Yang Mempengaruhi Postpartum Blues. JOM 2 (2). Di akses pada tanggal 29 April 2018. https://jom.unri.ac.id/index.php/JOMPSIK /article/view/8261

Fairus M \& Widiyanti F. (2014). Hubungan Dukungan Suami Dengan Kejadian Depresi Postpartm Blues pada Ibu Nifas. Jurnal Kesehatan Metro Sai Wawai 7 (1). Diakses pada tanggal 28 Desember 2017. https://ejurnal.poltekkestjk.ac.id/index.php/JKM/article/view/260

Fatimah, S. (2009). Hubungan dukungan suami dengan kejadian postpartum blues pada ibu primipara di ruang Bugenvile RSUD Tugurejo Semarang (Doctoral dissertation, Universitas Diponegoro). Diperoleh dari https://scholar.google.co.id/scholar?hl=id \&as_sdt $=0 \% 2 \mathrm{C} 5 \& \mathrm{q}=$ hubungan+dukunga n+suami+dengan+kejadian+postpartum $+\mathrm{b}$ lues+pada+ibu+primipara+\&btnG=\#d=gs cit $\& \mathrm{p}=\& \mathrm{u}=\% 2 \mathrm{Fscholar} \% 3 \mathrm{Fq} \% 3 \mathrm{Dinfo} \%$ 3A83-

NgF5Zpa8J\%3Ascholar.google.com\%2F
\%26output\%3Dcite\%26scirp\%3D0\%26hl $\% 3 \mathrm{Did}$

Friedman, Bowden \& Jones. (2014). Buku Ajar Keperawatan Keluarga. Jakarta: EGC. 2010

Jensen, Lowdermilk, Bobak. (2005). Buku Ajar Keperawatan Maternitas. Jakarta: EGC. 2004 .

Jhaquin A. (2010). Psikologi untuk Kebidanan. Yogyakarta: Nuha Medika.

Lowdermilk, Perry \& Casshion (2013). Keperawatan Meternitas. Edisi 8. Jakarta: EGC, 2013

Mansur H. (2009). Psikologi Ibu Dan Anak Untuk Kebidanan. Jakarta: Salemba Medika.

Menken E, Alexis, Dowd S, Stone. (2008). The Importance of Maternal Mental Health. Diakses pada tanggal $28 \quad$ Februari 2018. http://ebookcentral.pro.

Notokusumo. (2017). Karakteristik penyebab terjadinya depresi postpartum pada ibu primipara dan multipara. Jurnal keperawatan 5(1). Diakses pada tanggal 23 Desember 2017. http://jurnal.akpernotokusumo.ac.id/index.php/jkn/article/do wnload/51/48.

Quintero J, Rojo FS, Chapela E, Mora F, Fellix M. (2014). Postpartum Emotional Psychopathological Outcome. Diakses pada tanggal 5 Januari 2018. http://dx.doi.org/10.4172/23299126.1000162.

Rai S, Pathak A, Sharma I. (2015). Postpartum Psychiatric Disorder: Early Diagnosis Management. Diakses pada tanggal 28 Februari 2018. www.indianjpsychiatrry.org.

Afiyanti, Y. \& Rachmanwati, I., N. (2014). Metodologi Penelitian Kualitatif dalam Riset Keperawatan. PT Rajagrafindo Persada: Jakarta

Sulistiyanti A., \& Susanti WL. (2017). Analisa Faktor-Faktor Penyebab Terjadinya Baby Blues Syndrom pada Ibu Nifas. Infokes, 7(2). Diakses Pada Tanggal 28 Desember 2017.

http://www.apikescm.ac.id/ejurnalinfokes/ index.php/infokes/article/download/178/1 $\underline{58}$. 